Article

\title{
God, the Middle Term: Bonhoeffer, Kierkegaard, and Christ's Mediation in Works of Love
}

\author{
Koert Verhagen $\mathbb{D}$ \\ St Mary's College, School of Divinity, University of St Andrews, St Andrews KY16 9JU, UK; \\ kv31@st-andrews.ac.uk
}

Received: 1 January 2020; Accepted: 5 February 2020; Published: 8 February 2020

\begin{abstract}
In this article, I argue that in Works of Love Søren Kierkegaard stays true to his Lutheran roots in detailing an ethic of neighbor love that draws deeply on and unfolds the implications of the inseparable realities of justification and Christ's mediation in the social sphere. The article unfolds in two parts. Since neither of these realities are explicit in Works of Love, the first part considers Dietrich Bonhoeffer's account of Christ as mediator in order to provide a framework for thinking about and identifying their presence in Kierkegaard's thought. Engaging with Bonhoeffer in this manner is particularly useful, not least because he was deeply influenced by Kierkegaard and also stood in the Lutheran tradition, but also because although he outlines the expansive nature of Christ's mediatorial work to tantalizing effect, he never unfolds its concrete, ethical implications for the Christian life. With the key aspects of Bonhoeffer's account in mind, the second part of this article demonstrates and argues for an overlooked theological dynamic in Works of Love: namely, that Kierkegaard's account of God's mediation not only shares these keys aspects, but also unfolds the ethical implications of Christ's mediation for the Christian life.
\end{abstract}

Keywords: Kierkegaard; Bonhoeffer; Christology; mediation; justification; Works of Love; God-relationship; ethics

\section{Introduction}

In the Apology of the Augsburg Confession Article IV, justification by faith is shown to be a necessary entailment of Christ's status as mediator between God and humanity. "For how will Christ be the mediator if we do not use him as mediator in our justification and believe that for his sake we are accounted righteous? But to believe means to trust in Christ's merits, that because of him God wants to be reconciled to us." ${ }^{1}$ Although Philip Melanchthon penned these words, they are consonant with Martin Luther's understanding of the relationship between justification and Christ's mediation. In his 1535 Lectures on Galatians, Luther writes of the relationship more subjectively, asserting that to be justified by faith in Christ is simply to despair of one's own possibilities and works, and, with trembling confidence, to come before Christ the Mediator in search of grace. ${ }^{2}$ The connection between justification and Christ's mediation, is, then, clearly articulated as both a systematic and a subjective truth in Lutheran soteriology. The rectification of relationship with God and the gift of passive righteousness are impossible apart from Christ's mediatorial person and work.

However, Christ's mediation is not limited to the facilitation of a salvific transaction in which the human being is made right with God and after which becomes superfluous. In other words, Christ's gracious mediation is a necessary and ongoing reality in and by which right relationship with God is

1 (Tappert 1959, p. 116).

2 (Luther 1992, p. 275). 
not only established, but also maintained, guaranteed, and preserved. ${ }^{3}$ If this is the case, then it follows that Christ's mediation has ongoing relevance for the Christian life that must be taken seriously. Indeed, as will be shown below, both Bonhoeffer and Kierkegaard assume that Christ also mediates between human beings. Christ's mediation between God and humanity and between human beings are not two things, but rather two aspects of his office as mediator. In other words, it is through Christ the mediator that God's gracious justification and works of love are coordinated in the life of the Christian. As such, throughout this article I will draw on and refer to both aspects of Christ's mediatorial office.

In what follows, I will argue that, in Works of Love, Søren Kierkegaard stays true to his Lutheran roots in detailing an ethic of neighbor love that draws deeply on and unfolds the implications of the inseparable realities of justification and Christ's mediation in the social sphere. The article will proceed in two parts. Since neither of these realities are explicit in Works of Love, the first part will consider Dietrich Bonhoeffer's account of Christ as mediator in order to provide a framework for thinking about and identifying their presence in Kierkegaard's thought. Engaging with Bonhoeffer in this manner is particularly useful, not least because he was deeply influenced by Kierkegaard and also stood in the Lutheran tradition, but also because although he outlines the expansive nature of Christ's mediatorial work to tantalizing effect, he never has the chance to unfold its concrete, ethical implications for the Christian life. ${ }^{4}$ With the key aspects of Bonhoeffer's account in mind, the second part of this article will demonstrate and argue for an overlooked theological dynamic in Works of Love: namely, that Kierkegaard's account of God's mediation not only shares these keys aspects, but also unfolds the ethical implications of Christ's mediation for the Christian life.

\section{Bonhoeffer on Christ as Mediator}

The influence of Kierkegaard on Bonhoeffer is evident throughout the latter's works. ${ }^{5}$ In an article published in 1932, Bonhoeffer includes Kierkegaard in his brief genealogy of "genuine Christian thinking," alongside the Apostle Paul, Augustine, Luther, and Karl Barth. ${ }^{6}$ They also, of course, had in common a Lutheran confessional background, but were by no means slavish adherents to it. To this effect, Bonhoeffer, in a letter to his parents on 31 October, 1943, writes: "Already one hundred years ago Kierkegaard said that Luther today would say the opposite of what he said back then. I think this is true-cum grano salis." ${ }^{\prime 7}$ Indeed, they were both concerned to highlight the inseparable connection between what Luther in his time rightly emphasized—the "infinite humiliation of grace" —and what they saw as desperately needed in their own time, a "striving born of gratitude". ${ }^{8}$ As such, while there are of course important differences between Bonhoeffer and Kierkegaard-most notably Bonhoeffer's emphasis on the corporate and ecclesial nature of human existence, which stands in sharp contrast to Kierkegaard's stress on the single individual-they are natural dialogue partners. Yet, insofar as their relationship has been explored up to this point, it is often framed in terms of influence, resonance, or correction. Rarely, has it been considered that Bonhoeffer, as the more straightforward and traditionally theological thinker, might aid in illuminating and affirming the more subtle theological

3 (Luther 1959, p. 216). An implicit claim of this paper is that, for Bonhoeffer and Kierkegaard, justification, coordinated as it is by Christ's mediation, is both forensic and effective. However, a thorough account that maps their position in relation to ongoing Lutheran debates on this topic is beyond the scope of the article.

4 Although Bonhoeffer's Ethics is rightly understood as an unfolding Christ's comprehensive mediation in terms of the "Christ-reality" [Christuswirklichkeit], I follow Philip Ziegler in reading his moral theology as "pre-eminently metaethical in character" (Ziegler 2016, pp. 113-14).

5 Bonhoeffer's familiarity with Works of Love is evident as early as his doctoral thesis, Sanctorum Communio. See (Bonhoeffer 2009b, p. 169n28). For a thorough treatment of Kierkegaard's influence on Bonhoeffer, as well as the implicit resonances in their thought, see (Kirkpatrick 2011).

6 (Bonhoeffer 2008, p. 460).

7 (Bonhoeffer 2010, p. 173). Cf. (Kierkegaard 1990, p. 49).

8 (Kierkegaard 1967, p. 434). 
contours of Kierkegaard's thought. ${ }^{9}$ Here, I assume exactly that and thus will begin by outlining Bonhoeffer's construal of Christ's mediatorial work.

Bonhoeffer's first substantial description of Christ as mediator-in his 1933 Christology lectures—is aimed at explicating the broader implications and reality altering significance of the traditional association between Christ's salvific and mediatorial work. ${ }^{10}$ For Bonhoeffer, "The God-human Jesus Christ is the one who, in his pro-me structure, is present in his person to the church as Word, sacrament, and church-community."11 This manner of presence sets him in a specific relation to the world that Bonhoeffer then further defines in terms of Christ's status as mediator. Christ is pro-me as the one who mediates not only between God and humanity, but also between God and history and between God and nature. ${ }^{12}$ For the present purpose, however, my focus will be on his account of Christ as the mediator between God and humanity.

Crucially, for Bonhoeffer, Christ's mediatorial work means that he is both the boundary and the center of human existence. As the boundary, he reveals to humanity their separation from God in their finitude and sin. He also asserts, however, that Christ is the center of human existence, the one in whom and through whom human beings are created to be in right relation to God. Christ "stands there because I cannot, that is, he stands at the boundary of my existence and nevertheless in my place." ${ }^{13}$ Here, Bonhoeffer is implicitly invoking the logic of Luther's simul justus et peccator. Christ must be both the individual's boundary and center because "I am separated, by a boundary that I cannot cross, from the self that I ought to be. This boundary lies between my old self and my new self, that is, in the center between myself and me."14 Christ as the boundary is judgment on humanity in Adam, which represents its dying state. ${ }^{15}$ But, insofar as he is also the center of human existence, he overcomes the boundary and establishes humanity anew coram Deo. In this account, Bonhoeffer is clearly drawing on the logic of justification by faith, but he makes this explicit when he concludes by asserting: "That Christ is the center of our existence says that he is the judgment and justification."16

Bonhoeffer later expands on what it means for Christ to be the center and boundary of human existence in Discipleship. There he unfolds the logic of this construal of Christ's mediatorial status in order to show that Christ is not only the means by which Christians relate to God as new selves, but also the means by which they relate to all other aspects of reality in this way. Here, it is worth quoting him at length:

It is true, there is something which comes between persons called by Christ and the given circumstances of their natural lives. But it is not someone unhappily contemptuous of life; it is not some law of piety. Instead, it is life and the gospel itself; it is Christ himself. In becoming human, he put himself between me and the given circumstances of the world. I cannot go back. He is in the middle. He has deprived those whom he has called of every immediate connection to those given realities. He wants to be the medium; everything should happen only through Him. He stands not only between me and God, he also stands between me and the world, between me and other people and things. He is the mediator, not only between God and human persons, but also between person and person, and between person and reality.

9 One notable exception is (Rae 2002). However, even here Rae's article is primarily concerned to defend Kierkegaard against Barth's criticism, interacting with Bonhoeffer's theology of discipleship only briefly in order to affirm the theological impulse behind Kierkegaard's thinking.

10 See (Bonhoeffer 2008, p. 241), where he briefly articulates and affirms the traditional, confessional association.

11 (Bonhoeffer 2009a, p. 315). See (Hampson 2013, p. 215) on Kierkegaard's understanding of Christ as being pro me.

12 (Bonhoeffer 2009a, p. 324). "Christ's status as mediator must be proven in that he can [be] seen as the center of human existence, of history, and of nature."

13 (Bonhoeffer 2009a, p. 324).

14 (Bonhoeffer 2009a, p. 324).

15 Humanity in Adam and humanity in Christ are key anthropological categories for Bonhoeffer in Act and Being. See (Bonhoeffer 1996, pp. 136-47).

16 (Bonhoeffer 2009a, p. 325). 
Because the whole world was created by him and for him (John 1:3; 1 Cor. 8:6; Heb. 1:2), he is the sole mediator in the world. ${ }^{17}$

Christ, then, both stands in immediate relationship to the single individual as her center and mediates between her and all else as her boundary. Here too, Bonhoeffer grounds this reality in the reality of justification, which is implicit in baptism's sacramental enactment of the death and resurrection of the believer. "I am deprived of my immediate relationship to the given realities of the world, since Christ the mediator and Lord has stepped in between me and the world. Those who are baptized no longer belong to the world, no longer serve the world, and are no longer subject to it." 18 This also makes clear the negative implication of Christ's mediation-namely, that it problematizes unmediated relationships.

What, then, does it mean for Christ to mediate all given relationships and realities? Bonhoeffer takes this up in his classic description of Christian community in Life Together. ${ }^{19}$ There, Bonhoeffer counterintuitively asserts that "without Christ we would not know other Christians around us; nor could we approach them. The way to them is blocked by one's own ego. Christ opened up the way to God and one another." ${ }^{20}$ What initially presents itself as the promise of immediate relationship, then, turns out to be a dead end which turns the individual back in on herself. That Christ removes this road block means that his mediatorial relation to the Christian is not generic or innate, but is defined by "what Christ has done for me and to me." ${ }^{21}$ As such, it is on the basis of who Christ is as the mediator and what he has done in his salvific work that the Christian relates to her neighbor.

In contrast, Bonhoeffer describes the urge for immediate, emotional relationships. Emotional relationships are generated by "natural urges, strengths, and abilities of the human soul." 22 He goes on to associate desire and eros with emotional relationships and characterizes them as essentially self-centered. ${ }^{23}$ As such, emotional relationships seek "the complete intimate fusion of I and You." ${ }^{24}$ Thus, Bonhoeffer concludes that "everything that is originally and solely characteristic of the community mediated through Christ reappears in the nonmediated community of souls in a distorted form." 25 If we follow Bonhoeffer's logic, then insofar as relationships mediated by Christ are defined by God's gracious justification of the sinner, then immediate relationships are marked by self-justification, self-determination, and personal preference. Stated another way, immediate relationships are governed by human standards of love and worth, and have little concern for how God radically redefines these standards in and through Christ.

Bonhoeffer then goes on to critique specifically "'merely emotional' love of neighbor." 26 This sort of love is capable of great things-"unheard-of sacrifices", "fervent devotion", "visible results", and "stirring eloquence" - but is ultimately, he asserts, self-centered. "It loves [the neighbor], not as free persons, but as those who it binds to itself." 27 Ultimately, all the great things of which a merely emotional love is capable arise from a desire for the neighbor's reciprocation of love. As such, even when it appears to be serving the other, it is actually serving itself.

17 (Bonhoeffer 2001, p. 93).

18 (Bonhoeffer 2001, pp. 207-8).

19 It should be noted that, in Life Together, Bonhoeffer's context and intended audience leads him to speak specifically of the need for Christologically mediated relationships between Christians. However, given his strong assertion in Ethics that God has reconciled the world in Christ (Bonhoeffer 2005a, pp. 55-66), it is clear that Christians should understand all their relationships as Christologically mediated.

20 (Bonhoeffer 2005b, p. 33).

21 (Bonhoeffer 2005b, p. 34). "What Christians are in themselves, in their inwardness and piety, cannot constitute the basis of our community, which is determined by what those persons are in terms of Christ."

22 (Bonhoeffer 2005b, p. 38).

23 (Bonhoeffer 2005b, pp. 39-40).

(Bonhoeffer 2005b, p. 41).

(Bonhoeffer 2005b, p. 41).

(Bonhoeffer 2005b, p. 42).

(Bonhoeffer 2005b, p. 42). 
Standing in stark contrast to merely emotional love is what Bonhoeffer terms "spiritual love". It "comes from Jesus Christ; it serves him alone. It knows that it has not direct access to other persons. Christ stands between me and others." 28 Because Christ stands between the Christian and the other as mediator, love is no longer determined by its object in an immediate sense but receives its definition from the command of Christ. For this reason, the Christian is not only able to but must love all people as a brother or sister, even their enemies. ${ }^{29}$ In other words, the love of Christ for others determines and is the basis for all genuine love. It means that the other's freedom before God is preserved from the coercion and domination of immediate, self-centered love. Thus, Bonhoeffer concludes:

In their freedom from me, other persons want to be loved for who they are, as those for whom Christ became a human being, died, and rose again, as those for whom Christ won the forgiveness of sins and prepared eternal life... They should encounter me only as the persons that they already are for Christ. This is the meaning of the claim that we can encounter others only through the mediation of Christ. Self-centered love constructs its own image of other persons, about what they are and what they should become. It takes the life of the other person into its own hands. Spiritual love recognizes the true image of the other person as seen from the perspective of Jesus Christ. It is the image Jesus Christ has formed and wants to form in all people. ${ }^{30}$

Christ's mediation means that the freedom of the other is affirmed and the Christian is set free to love the other in a manner that is determined by Christ and his salvific work. Spiritual love is always and at all times dependent on the gracious mediation of the present Christ.

While the resonances with Kierkegaard are especially clear where Bonhoeffer speaks directly to the mediated nature of Christian love in Life Together, there are a number of important aspects of the preceding account to review and highlight, which will in turn serve to illuminate the role that the connection between justification and Christ's mediation plays in Works of Love. First, as mentioned above, in the Christology lectures, Bonhoeffer proposes that Christ's mediatorial status means he stands at the center and boundary of human existence. As such, he not only mediates between God and human beings, but also between the individual and herself. Second, in Discipleship, he expands his account of mediation to emphasize the fact that Christ mediates between persons. For this reason, immediate relationships to others and the given realities of the world are inimical to Christianity. Finally, in Life Together, Bonhoeffer contrasts mediated, spiritual ways of relating to the other with immediate, emotional forms of relation. The former are possible only in light of the inward and outward effects of Christ's mediation. Inwardly, Christ mediates between the Christian and herself, enabling her to relate to the other as the new self she ought to be. Outwardly, Christ mediates between the Christian and the other, enabling the Christian to love her neighbor in their freedom and distinctiveness as one for whom Christ lived, died, and was resurrected. Finally, as a red thread running throughout, it is clear that, for Bonhoeffer, the justificatory person and work of Christ not only entail his mediatorial status, but also shape the sort of relationships which Christ's mediation establishes. With these points in mind, I will now turn to show how Bonhoeffer's account provides an occasion for considering oft-overlooked theological dynamics undergirding Kierkegaard's account of neighbor love, before concluding with the suggestion that Works of Love functions as a sort of ethics of Christ's mediation.

\section{Kierkegaard and Christ's Mediation}

One of the reasons it is particularly useful to read Kierkegaard alongside a theologian like Bonhoeffer relates to the fact that Kierkegaard took Christian doctrines to be presuppositional and as such, rarely addresses them explicitly. In the introduction to The Concept of Anxiety,

\footnotetext{
(Bonhoeffer 2005b, p. 43).

29 (Bonhoeffer 2005b, p. 43).

30 (Bonhoeffer 2005b, p. 44).
} 
Kierkegaard—writing under the pseudonym, Vigilius Haufniensis—makes the claim that faith entails a "historical presupposition." Likewise, dogmatics must assume an "earlier beginning." 31 What does Kierkegaard mean by this? This becomes clear several pages later when he asserts that "dogmatics must not explain hereditary sin but rather explain it by presupposing it, like that vortex about which Greek speculation concerning nature had so much to say, a moving something that no science can grasp." ${ }^{\prime 2}$ While Kierkegaard's attitude toward historical expressions of Christian doctrine is, on the surface, ambivalent, it would seem that his appreciation for doctrine is directly correlated to the manner in which Christianity unfolds its presuppositional content in order to "move individuals in certain ways." ${ }^{\prime 3}$ As such, Lee Barrett suggests that "a doctrinal concept can permeate an expansive swath of Kierkegaard's authorship without being made explicit." ${ }^{34}$

Philip Ziegler has made a parallel suggestion regarding the way in which Kierkegaard's thinking on the Christian life is importantly structured by soteriological concerns. ${ }^{35}$ Ziegler exposits Haufniensis' concept of a 'second ethics,' also put forward in the introduction to The Concept of Anxiety, as "a new ethics that 'presupposes dogmatics', that is, which takes as its ground the dogmatic description of the actuality of human sinfulness and the work of divine grace upon the truth of which all other ethics are simply 'shipwrecked'."36 There is, therefore, no human subject as such, but only the individual who exists coram Deo as a sinner in need of grace. Insofar as the God-relationship is decisive for Kierkegaard's understanding of Christian ethics, ${ }^{37}$ it is impossible to separate the soteriological contours of that relationship from his provocative and polemical accounts of the Christian life.

Furthermore, that the soteriological shape of the God-relationship might be specifically governed by the logic of justification by faith is hardly far-fetched. Indeed, in his most extensive interaction with Luther, in For Self-Examination, Kierkegaard affirms that his emphasis on striving presupposes the logic of justification: "Christianity's requirement is this: your life should express works as strenuously as possible; then one thing more is required-that you humble yourself and confess: But my being saved is nevertheless grace." 38 Daphne Hampson asserts that Works of Love is "deeply Lutheran" and as such, evinces exactly this dynamic. ${ }^{39}$ One of the ways she then explains what it means to be Lutheran is in terms of the belief that "to say that we are 'justified by faith' is to say that we stand in right relation to God; accepted, as we trust in God's acceptance of us. The corollary of such acceptance (irrespective of merit) is that freed from the insecurity of concern about our acceptance we are in turn set free to love the neighbour with a like love to that with which God has loved us, without preconditions." 40 Likewise, David Gouwens asserts that "Kierkegaard is firmly within the 'Lutheran fold' on justification," but goes on to suggests that he engages it as a "contextual rather than doctrinal theologian." 41

What, then, of Christ's mediation? In Kierkegaard's journals, there is conflicting evidence as to how important Kierkegaard thought this was for the God-relation. On the one hand, he suggests that human beings can relate to God without a mediator, calling it a "child-relationship." 42 On the other, hand he asserts that the central untruth of Stoicism is its "wanting to be related directly to

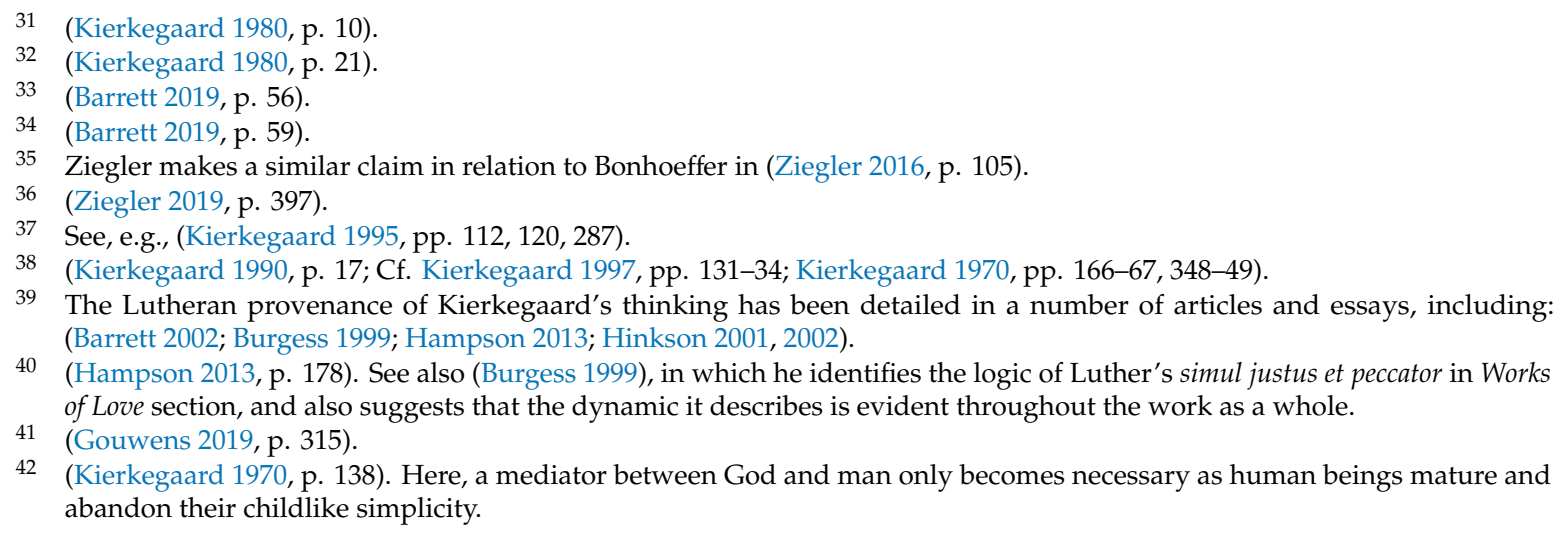

40 (Hampson 2013, p. 178). See also (Burgess 1999), in which he identifies the logic of Luther's simul justus et peccator in Works of Love section, and also suggests that the dynamic it describes is evident throughout the work as a whole.

41 (Gouwens 2019, p. 315).

42 (Kierkegaard 1970, p. 138). Here, a mediator between God and man only becomes necessary as human beings mature and abandon their childlike simplicity. 
God (without a mediator)." 43 However, in the same passage where he suggests the possibility of an unmediated relation to God, he concludes that God "becomes my Father in the Mediator by means of the Spirit." 44 Ultimately, Kierkegaard rarely speaks of Christ as Mediator. ${ }^{45}$ This is likely due to his consistent polemic against Hegelian construals of mediation as the "reconciliation of opposites in a higher unity." ${ }^{\prime 6}$ Insofar as Kierkegaard implicitly affirms Christ as Mediator, it is important to note that Christ never ceases to be a "sign of contradiction." ${ }^{47}$ In other words, Christ does not mediate between God and humanity by uniting them in a way that makes direct communication possible and thus bypasses faith. Indeed, he asserts that "modern confusion has managed to make all Christianity into direct communication only by leaving out the communicator, the God-man." 48 Thus, relationship with and knowledge of God is always and at every moment dependent on faith in the God-man and his indirect communication.

It is reasonable, then, to assume that Kierkegaard is committed to the doctrines of justification and Christ's mediation, even if they are characteristically understated or implicit in his thinking. Insofar as Bonhoeffer's account of Christ as mediator is relevantly similar to Kierkegaard's description of God's mediation in Works of Love, it provides an occasion and a framework for considering how these doctrines inform what it means for God to serve as the middle term between a person and her neighbor. Before turning to consider the presence of a theology of justification and Christ's mediation in Works of Love, it is important to note that Kierkegaard never speaks explicitly of mediation in the text. Furthermore, his most straightforwardly mediatorial language — "middle term" and "God-relationship" - refers simply to God rather than to Christ specifically. As such, there are two tasks at hand. The first task is to make the case that the logic of justification and mediation are indeed present and play an important role in structuring Kierkegaard's ethic of neighbor love. As I do this, I will work with his language and refer simply to God as performing mediatorial work between the Christian and her neighbor. The second task will be to argue that the work Kierkegaard attributes to divine mediation and the way he grounds it in justification is sufficiently similar to Bonhoeffer's account to warrant reading Works of Love as an ethics of Christ's mediation.

"Romans 13:10. Love is the Fulfilling of the Law" serves as the christological and soteriological heart of Works of Love. ${ }^{49}$ Indeed, it might be understood as expositing Kierkegaard's address of Christ in the Trinitarian prayer with which he opens the book: "How could one speak properly about love if you were forgotten, you who revealed what love is, you our Savior and Redeemer, who gave yourself in order to save all." ${ }^{\prime \prime 0}$ He begins by imagining that Paul's assertion that love is the fulfilling of the law is his answer to an anonymous questioner who has asked "What is love?"51 Such an answer points to the fact that love does not make space for reflection, nor does it endorse superficial busyness. Instead, it is "whole and collected, present in its every expression, and yet it is sheer action." 52 However, Kierkegaard recognizes that to define Christian love in this way narrows the field of those who have loved Christianly to one person: Jesus Christ, the one "who was love." 53 Stated another way, if Jesus is

\footnotetext{
(Kierkegaard 1975, p. 334).

(Kierkegaard 1970, p. 140).

Some exceptions include (Kierkegaard 1970, pp. 45, 133).

(Kierkegaard 1985, p. 279, Cf. 222-24). On this and the importance of Christ's mediation for Kierkegaard's theology, see (Torrance forthcoming). My thanks to Andrew Torrance for providing me with a pre-publication version of this article.

49 This is a point that is not always recognized. Hampson, for example, completely ignores the soteriological and christological dimensions of the passage (Hampson 2013, pp. 191-94). Contrast this with Paul Martens, who, with reference to this section, writes: "One does not need to refer to Philosophical Fragments to understand the importance Kierkegaard attaches to the historical existence of the revealer of love. Works of Love spells it out very clearly" (Martens 1999, pp. 72-74).

50 (Kierkegaard 1995, p. 3).

51 (Kierkegaard 1995, p. 95).

52 (Kierkegaard 1995, p. 98).

53 (Kierkegaard 1995, p. 99).
} 
love, then fulfilling of the law becomes the Christian definition of love because this is what Jesus did. As such, love's requirement exists only in its perfect fulfillment.

In this sense, Christ certainly serves as the prototype. "[B]y abiding in love every Christian works so that his love might become like this [perfect fulfillment in Christ]." ${ }^{\prime 54}$ Importantly, however, it is only by abiding in love that such striving after the prototype is made possible. Furthermore, abiding in Christ's loving fulfillment of the law is not a human possibility because, as Kierkegaard notes, "to speak about love as the fulfilling of the Law is of course an impossibility without simultaneously acknowledging one's own guilt and making every human being guilty." 55 There remains a chasm between Christ and human beings on account of their guilt before the law's requirement. Thus, Christ's redemptive work is the prerequisite for striving after his prototypical love in law fulfillment. Here, it is worth quoting Kierkegaard at length:

And yet [Christ] was love, and yet he did everything out of love and wanted to bring salvation to humanity, and by what means? By the relationship with God-because he was love. Yes, he was Love, and he knew in his innermost being and in responsibility before God that it was the sacrifice of Atonement that he was bringing, that he truly loved the disciples, loved the whole human race, or in any case everyone who would allow himself to be saved! ${ }^{56}$

Three factors are at play in this brief but powerful account of Christ's redemptive work. First, Kierkegaard affirms that Christ is love three times and, as he has already established, love is the fulfilling of the law. Second, Christ brings salvation to humanity by re-establishing relationship with God. Third, the means by which Christ re-establishes this relationship is his sacrifice of atonement. Taken together, this means that Christ sets humanity in right relationship to God by atoning for their guilt before the law's requirement and by making possible their abiding in him, his love, his own, perfect law-fulfillment. This is "the divine explanation of what love is." ${ }^{\prime 57}$ Christians are set free to strive after Christ's prototypical law-fulfillment on the basis of this love and from within the God-relationship for which Christ redeems them and in which he establishes them.

For Kierkegaard, Christ's salvific work in rectifying the God-relationship is that which makes love for the neighbor possible. Intertwined with his account of Christ's central significance in fulfilling the law and redemption, Kierkegaard explains why the God-relationship is so important. He writes that, contrary to the world's assumption "that love is a relationship between persons; Christianity teaches that love is a relationship between: a person-God-a person, that is, that God is the middle term." ${ }^{58}$ The omission of God from the love relationship —even when it is accompanied by grand gestures, sacrifice, and eloquence—can only ever be "a mutually enchanting defraudation of love." 59

What, then, are the resultant dynamics of a love relationship in which God is the middle term? "To love God is to love oneself truly; to help another person to love God is to love another person; to be helped by another person to love God is to be loved." ${ }^{\prime 60}$ Nowhere does Kierkegaard straightforwardly unpack this triadic relation, but there seem to be two ways of construing its meaning. ${ }^{61}$ First, it could mean that, on the one hand, self-love is mediated by God, while, on the other hand, love of another person is appropriately direct since it helps her to love God and therefore herself. ${ }^{62}$ Second, it could mean that not only is proper self-love mediated by God, so too is love for the other person. In other

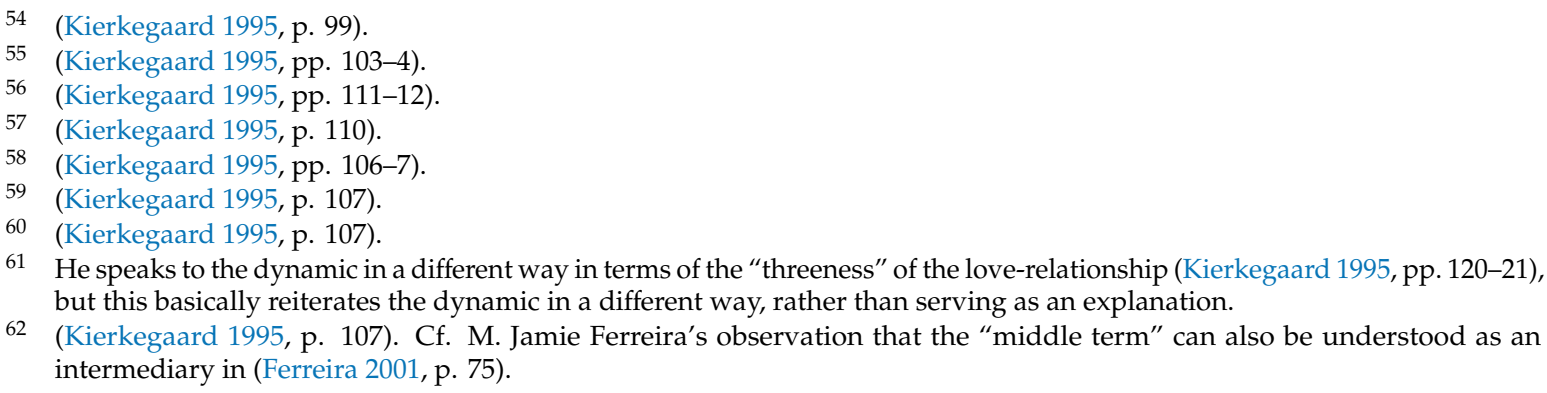

62 (Kierkegaard 1995, p. 107). Cf. M. Jamie Ferreira's observation that the "middle term" can also be understood as an intermediary in (Ferreira 2001, p. 75). 
words, only in and through the God-relation can a Christian encounter another person as one who is loved by God and intended to be in loving relationship with him. The latter interpretation seems to capture Kierkegaard's intent better insofar as he asserts that, on a Christian understanding of interpersonal love, not only must each individual be related to God, but also that the relationship of love exists only on this basis. Furthermore, "God is the middle term in judging love" and performs a "double judgment": he judges against human definitions of love which arise from direct relations between persons, and judges for "the divine explanation of what love is." ${ }^{\prime \prime 3}$ Thus, even well-intentioned love, if it is directly related to the other, must be mediated by God's double judgment as the middle term.

It is no accident that Kierkegaard's discussion of the central significance of God as the middle term and the God-relationship is intertwined with his description of Christ's perfectly law fulfilling love and salvific re-establishment of humanity coram Deo. Indeed, the God-relation, which is so central to Kierkegaard's account of love is unthinkable apart from Christ's fulfillment of the law and sacrifice of atonement. ${ }^{64}$ As such, relating to God as the middle term cannot be abstracted from the christological basis on which such a relation is even possible. Christ's mediation is then also materially central to what it means for the Christian to relate to another person. This comes out when, after having outlined Christ's salvific, love-defining role, Kierkegaard reiterates the triadic relationship between the Christian, God, and the other in a slightly different manner: "The essentially Christian is this: truly to love oneself is to love God; truly to love another person is with every sacrifice (also the sacrifice of becoming hated oneself) to help the other person to love God or in loving God." ${ }^{65}$ Christ's loving fulfillment of the law and sacrifice of atonement are not only salvific for the Christian, they are also prototypical in shaping love for the other. There are, however, two other ways which Christ's person and work is materially significant for the love relationship. First, Christ is the justification of love for the other person insofar as that person is also one for whom Christ sacrificed himself. ${ }^{66}$ Second, Christ shapes the aim of the God-mediated love relationship since, if the goal is to help the other person love God it has as its presupposition and possibility the love of Christ in his fulfillment of the law and in his atoning sacrifice. Thus, God's mediating work as the middle term in Christian love for the other is thoroughly intertwined with and related to the loving person and work of Christ.

Having outlined Kierkegaard's intertwining of the soteriological and mediatorial at the heart of his account of Christian love, it is now possible to make explicit its compatibility with the key points of Bonhoeffer's rendering of Christ as mediator that were noted in the conclusion to the previous section. First, by relating justification and Christ's mediation as inseparable realities, Kierkegaard stays true to his Lutheran roots, but, like Bonhoeffer, does so in a way that pushes toward a more comprehensive account of God's mediation. Second, Kierkegaard's consistent assertion that proper self-love is love for God corresponds to Bonhoeffer's claim that Christ is both the center and the boundary of human existence. Christ stands at the boundary between the old self and the new self, passing judgment on the old self's pretensions to self-determination and improper self-love. But he is also the center out of which the new self lives, and as such, love of self is transformed into love of God in Christ. Third, and perhaps most directly, just as, for Bonhoeffer, Christ mediates between persons, so too, for Kierkegaard, does God serve as the middle term between persons. Fourth and finally, Kierkegaard's triadic model of interpersonal love corresponds to Bonhoeffer's claim that spiritual love must involve both inward and outward mediation. Inward mediation assures that the individual is rightly related to herself and God as a new self in Christ, while outward mediation assures that the Christian relates to

63 (Kierkegaard 1995, p. 107).

64 Cf. (Kierkegaard 1995, p. 336).

65 (Kierkegaard 1995, p. 114).

66 Cf. (Kierkegaard 1995, p. 69). While this does not contradict C. Stephen Evans' suggestion that the image of God in all people makes sense of the God-relation and God as the middle term in neighbor love (Evans 2004, pp. 193-94), it does point to the need for contextualizing the imago Dei in relation to Christology and soteriology. 
other people on the basis of their God-relationship, approaching them as free individuals who God loves because Christ lived, died, and was resurrected for them.

Given this close correspondence, what then should one make of the fact that Kierkegaard never refers to Christ's mediation in Works of Love and only speaks of the God-relationship and God as the middle term? One simple answer would be to suggest a Trinitarian resolution in which, when Kierkegaard says God, he always also means Christ. However, this cannot be the case because when Kierkegaard speaks of the means by which Christ wanted to bring salvation he does not say "by relationship with himself," but rather, "by the relationship with God." ${ }^{\prime 67}$ It may then be more accurate to say that when Kierkegaard speaks of God as the middle term and the God-relation he assumes Christ's person as a member of the Godhead. ${ }^{68}$ There are at least three reasons to think this is the case. First, as outlined above, it is highly unlikely that Kierkegaard is envisaging a direct relationship with God. ${ }^{69}$ Second, alongside God, the neighbor is also identified with the middle term in Works of Love. Kierkegaard uses "the neighbor" to refer to two different, if related, things. It can either refer to the concrete other who one encounters through God, or it can refer to a fundamental category "like the category "human being.'" 70 Every concrete neighbor is also a member of the category "neighbor." The category "neighbor", for Kierkegaard, is thoroughly christological in nature because it is based on a universal kinship, which "is secured by each individual's equal kinship with and relationship to God in Christ; because the Christian doctrine addresses itself equally to each individual, teaches him that God created him and Christ redeemed him." ${ }^{\text {"71 }}$ Thus, the "neighbor" as a middle term designates the other person's relationship with God which is established through Christ's redemptive work. Third, elsewhere in Works of Love, Kierkegaard refers to God with reference to the atonement when Christ is clearly in view as the primary referent: "No, God loved us first; and again the second time, when it was a matter of the Atonement [Forsoningen], God was the one who came first--although in the sense of justice he was the one who had the furthest to come." 72

Understood in this way, Kierkegaard's preference for speaking of God when it comes to mediation does not contradict or preclude the dynamics of Bonhoeffer's Christocentric account, as shown above. On the contrary, Bonhoeffer's account helps illuminate that Kierkegaard's account of love is latently informed by his theological commitment to the mediatorial work and person of Jesus Christ. Indeed, one might say that it provides firm ground for developing an ethics of Christ's mediation. What remains to be seen is exactly how Kierkegaard's wider exposition of neighbor love might be understood as an unfolding of the ethical implications of Christ's mediation. While a comprehensive account of this sort is beyond the scope of this article, in the next section I will identify two other places in Works of Love's first discourse where Kierkegaard invokes God as the middle term and consider how these passages might be interpreted in light of Christ's mediatorial role in establishing the God-relationship.

\section{Conclusions}

Consideration of the explicit invocations of God as the middle term in the first discourse reveals that this reality plays two important roles in enabling and defining love for the neighbor. ${ }^{73}$ Because Kierkegaard invokes this conceptuality without explaining exactly what he means by it, it is theologically

67 (Kierkegaard 1995, p. 111).

68 Lee Barrett describes a similar sort of dynamic - where an attribute is ascribed to God, but its content is most centrally understood in and through the person of Christ-in relation to God's self-emptying in the incarnation. He asserts that, for Kierkegaard, God is primarily characterized by self-giving love (Barrett 2013, p. 196), which is most fully revealed in Jesus's voluntary self-abasement (Barrett 2013, p. 311-12).

69 See (Kierkegaard 1992, p. 243). "The direct relationship with God is simply paganism, and only when the break has taken place, only then can there be a true God-relationship."

70 (Kierkegaard 1995, p. 141). Pace (Ferreira 2001, p. 75), who seems to assume that the concrete neighbor is the middle term.

71 (Kierkegaard 1995, p. 69).

72 (Kierkegaard 1995, p. 336). Emphasis added.

73 There is a third instance (Kierkegaard 1995, p. 77), but it is parenthetical and overlaps with much of the substance of the other two instances. As such, I will not treat it here. 
pertinent to read his fuller exposition of the concept in "Romans 13:10. Love is the Fulfilling of the Law" back into these two instances. Given what has been suggested above regarding this exposition, these earlier instances can and should be read in light of the christological and soteriological substance of God's mediation. In what follows, I will demonstrate just such an interpretation before concluding with the suggestion that Kierkegaard takes the four aspects of Christ's mediation which he and Bonhoeffer share in common and puts them to work in the ethical sphere in a way that goes beyond Bonhoeffer. ${ }^{74}$

First, Kierkegaard asserts that God as the middle term in neighbor love distinguishes it from self-love, as well as preferential love. ${ }^{75}$ Preferential love, which is ultimately self love, is, in a certain sense, an attempt at self-deification. It makes the individual the arbiter in deciding who is worthy of love, evaluating them according to one's own standards and desiring them for oneself. In preferential love, love itself is the middle term between the lover and the one who is loved. However, insofar as preferential love is self-love it is, in actuality, not really a middle term. Rather, preferential love is an immediate relationship in which the other is fused with the I and loved only on the basis of this sameness. Neighbor love is, then, the exact opposite. It introduces God as the decisive middle term who is to be loved above all else. In doing so it makes possible love for "the neighbor and in the neighbor every human being." ${ }^{16}$ How does it do this? By judging preferential love, lovingly establishing the one who loves in Christ's perfect fulfillment of the law, and revealing the neighbor as the one who God loves in Christ. Thus, the neighbor is a category which includes every human being because Christ fulfilled the law and was the sacrifice of atonement for all.

Second, God as the middle term prevents the lover from taking a self-oriented pride in her works. "[T]here is no pride or haughtiness in this wealth, because God is the middle term, and eternity's shall binds and guides this great need so that it does not go astray and turn into pride."77 Because God is the middle term, the Christian is always reminded of the infinite requirement and of the impossibility of fulfilling it. God's requirement levels the playing field because all are equal in their falling short. More positively, God as the middle term means that Christ has perfectly fulfilled the law and sacrificed himself so that Christians can strive after the requirement as those for whom it has already been fulfilled. God's mediation also reminds Christians that their old self is sinful and can achieve nothing, but their new self is with God in Christ who has achieved everything.

These two explicit invocations of God as the middle term demonstrate that the soteriological and mediatorial relevance of Christ is hardly peripheral to Kierkegaard's thinking in Works of Love. Nor is it constrained to one section of the work. Indeed, the issues of non-preferential love and universal human equality before God play central roles in Kierkegaard's exposition of neighbor love. Furthermore, the four key aspects of Bonhoeffer's account are present in making sense of how God's mediation militates against preference and pride: Christ stands between the individual and God, the individual and herself, and the individual and the other as the one who lived, died, and was resurrected in order to make humanity right with God. As such, the emphasis Kierkegaard places on God's mediation of neighbor love in Works of Love not only parallels Bonhoeffer's account, it also draws out its implications for Christian ethics in relation to the non-preferential nature of Christian love and universal human equality before God.

Funding: This work was funded by the Templeton Religious Trust [TRT0095/58801].

Conflicts of Interest: The author declares no conflicts of interest.

74 There is a certain irony in suggesting that Kierkegaard went beyond Bonhoeffer in this manner since the latter's biography is characterized by concrete ethical action in a way that the former's is not. However, the fact remains that if one accepts that Christ's mediation is central to Works of Love, then Kierkegaard offers a much more thoroughgoing account of its implications for a Christian love ethic than does Bonhoeffer.

75 (Kierkegaard 1995, pp. 57-58). Here, Kierkegaard distinguishes between self-love and these two paradigmatic forms of preferential love, but earlier he equates self-love with preferential love (p. 53).

76 (Kierkegaard 1995, p. 58).

77 (Kierkegaard 1995, p. 67). 


\section{References}

Barrett, Lee C. 2002. Faith, Works, and Uses of the Law: Kierkegaard's Appropriation of Lutheran Doctrine. In International Kierkegaard Commentary: For Self-Examination and Judge for Yourself! Edited by Robert L. Perkins. Macon: Mercer University Press.

Barrett, Lee C. 2013. Eros and Self-Emptying: The Intersections of Augustine and Kierkegaard. Eerdmans: Grand Rapids.

Barrett, Lee C. 2019. Kierkegaard on Doctrine: The Grammar of Christian Pathos. In TET Clark Handbook of the Theology of Kierkegaard. Edited by Aaron P. Edwards and David J. Gouwens. London: T\&T Clark.

Burgess, Anthony. 1999. Kierkegaard's Concept of Redoubling and Luther's Simul Justus. In International Kierkegaard Commentary: Works of Love. Edited by Robert L. Perkins. Macon: Mercer University Press.

Bonhoeffer, Dietrich. 1996. Act and Being: Transcendental Philosophy and Ontology in Systematic Theology. Edited by Wayne Whitson Floyd Jr. Translated by H. Martin Rumscheidt. Minneapolis: Fortress Press.

Bonhoeffer, Dietrich. 2001. Discipleship. Edited by Geffrey B. Kelly and John D. Godsey. Translated by Barbara Green, and Reinhard Krauss. Minneapolis: Fortress Press.

Bonhoeffer, Dietrich. 2005a. Ethics. Edited by Clifford J Green. Translated by Reinhard Krauss, Charles C. West, and Douglas W. Stott. Minneapolis: Fortress Press.

Bonhoeffer, Dietrich. 2005b. Life Together and Prayerbook of the Bible. Edited by Geffrey B. Kelly. Translated by Daniel W. Bloesch, and James H. Burtness. Minneapolis: Fortress Press.

Bonhoeffer, Dietrich. 2008. Barcelona, Berlin, New York: 1928-1931. Edited by Clifford J. Green. Translated by Douglas W. Stott. Minneapolis: Fortress Press.

Bonhoeffer, Dietrich. 2009a. Berlin: 1932-1933. Edited by Larry L. Rasmussen. Translated by Isabel Best, and David Higgins. Minneapolis: Fortress Press.

Bonhoeffer, Dietrich. 2009b. Sanctorum Communio: A Theological Study of the Sociology of the Church. Edited by Clifford J. Green. Translated by Reinhard Krauss, and Nancy Lukens. Minneapolis: Fortress Press.

Bonhoeffer, Dietrich. 2010. Letters and Papers from Prison. Edited by John W. de Gruchy. Translated by Isabel Best, Lisa E. Dahill, Reinhard Krauss, and Nancy Lukens. Minneapolis: Fortress Press.

Evans, C. Stephen. 2004. Kierkegaard's Ethic of Love: Divine Commands and Moral Obligations. Oxford: Oxford University Press.

Ferreira, M. Jamie. 2001. Love's Grateful Striving: A Commentary on Kierkegaard's Works of Love. Oxford: Oxford University Press.

Gouwens, David J. 2019. Justification: 'The Article by Which the Church Stands or Falls'? In TET Clark Handbook of the Theology of Kierkegaard. Edited by Aaron P. Edwards and David J. Gouwens. London: T\&T Clark.

Hampson, Daphne. 2013. Kierkegaard: Exposition and Critique. Oxford: Oxford University Press.

Hinkson, Craig. 2001. Luther and Kierkegaard: Theologians of the Cross. International Journal of Systematic Theology 3: 27-45. [CrossRef]

Hinkson, Craig Q. 2002. Will the Real Martin Luther Please Stand Up! Kierkegaard's View of Luther vs. the Evolving Perceptions of the Tradition. In International Kierkegaard Commentary: For Self-Examination and Judge for Yourself! Edited by Robert L. Perkins. Macon: Mercer University Press.

Kierkegaard, Søren. 1967. Søren Kierkegaard's Journals and Papers, Volume 1, A-E. Edited and Translated by Howard V. Hong and Edna H. Hong. Bloomington: Indiana University Press.

Kierkegaard, Søren. 1970. Søren Kierkegaard's Journals and Papers, Volume 2, F-K. Edited and Translated by Howard V. Hong and Edna H. Hong. Bloomington: Indiana University Press.

Kierkegaard, Søren. 1975. Søren Kierkegaard's Journals and Papers, Volume 4, S-Z. Edited and Translated by Howard V. Hong and Edna H. Hong. Bloomington: Indiana University Press.

Kierkegaard, Søren. 1980. The Concept of Anxiety: A Simple Psychologically Orienting Deliberation on the Dogmatic Issue of Hereditary Sin. Edited and Translated by Reidar Thomte. Princeton: Princeton University Press.

Kierkegaard, Søren. 1985. Philosophical Fragments. Edited and Translated by Howard V. Hong and Edna H. Hong. Princeton: Princeton University Press.

Kierkegaard, Søren. 1990. For Self-Examination; Judge for Yourself! Edited and Translated by Howard V. Hong and Edna H. Hong. Princeton: Princeton University Press.

Kierkegaard, Søren. 1991. Practice in Christianity. Edited and Translated by Howard V. Hong and Edna H. Hong. Princeton: Princeton University Press. 
Kierkegaard, Søren. 1992. Concluding Unscientific Postscript to Philosophical Fragments. Edited and Translated by Howard V. Hong and Edna H. Hong. Princeton: Princeton University Press.

Kierkegaard, Søren. 1995. Works of Love. Edited and Translated by Howard V. Hong and Edna H. Hong. Princeton: Princeton University Press.

Kierkegaard, Søren. 1997. Without Authority. Edited and Translated by Howard V. Hong and Edna H. Hong. Princeton: Princeton University Press.

Kirkpatrick, Matthew D. 2011. Attacks on Christendom in a World Come of Age: Kierkegaard, Bonhoeffer, and the Question of "Religionless Christianity.". Eugene: Pickwick Publications.

Luther, Martin. 1959. Luther's Works, Volume 36: Word and Sacrament II. Edited by Adel Ross Wentz. Philadelphia: Fortress Press.

Luther, Martin. 1992. Luther's Works, Volume 27: Lectures on Galatians, 1535, Chapters 5-6; 1519, Chapters 1-6. Edited by Jaroslav Pelikan. Saint Louis: Concordia Publishing House.

Martens, Paul. 1999. "You Shall Love": Kant, Kierkegaard, and the Interpretation of Matthew 22:39. In International Kierkegaard Commentary: Works of Love. Edited by Robert L. Perkins. Macon: Mercer University Press.

Rae, Murray. 2002. Kierkegaard, Barth, and Bonhoeffer: Conceptions of the Relation between Grace and Works. In International Kierkegaard Commentary: For Self-Examination and Judge for Yourself! Edited by Robert L. Perkins. Macon: Mercer University Press.

Tappert, Theodore G., ed. 1959. The Book of Concord: The Confessions of the Evangelical Lutheran Church. Philadelphia: Mühlenberg Press.

Torrance, Andrew. forthcoming. Kierkegaard's Paradoxical Christology. Participatio.

Ziegler, Philip G. 2016. "Completely within God's Doing": Soteriology as Meta-Ethics in the Theology of Dietrich Bonhoeffer. In Christ, Church, and World: New Studies in Bonhoeffer's Theology and Ethics. Edited by Michael Mawson and Philip G. Ziegler. London: Bloomsbury T\&T Clark.

Ziegler, Philip G. 2019. The Christian Life: A Humble Striving Born of Gratitude. In TET Clark Handbook of the Theology of Kierkegaard. Edited by Aaron P. Edwards and David J. Gouwens. London: T\&T Clark.

(C) 2020 by the author. Licensee MDPI, Basel, Switzerland. This article is an open access article distributed under the terms and conditions of the Creative Commons Attribution (CC BY) license (http://creativecommons.org/licenses/by/4.0/). 